ents were recovered are in keeping with conjugal mating rather than phage transduction. Lowbury et al. ${ }^{1}$ eliminated high level carbenicillin rosistance of these strains of Pseudomonas with acriflavine and suggested that the resistance came from extrachromosomal $R$-factors. The data presented here confirm the presence in these carbonicillin-resistant strains of $P s$. aeruginosa of an extrachromosomal $R$-factor which mediates $\beta$-lactamaso production.

The $\beta$-lactamase of the transcipient $E$. coli K12-1822 $R$ was characterized by investigating the substrate spectrum and inhibition profile. The $K_{m}$ value for its $\beta$-lactamase was also measured.

Table 1 shows that the transcipient has a substrate spectrum comparable with those of the carbenicillinresistant strains. The $K_{m}$ value (Fig. 1) of the $\beta$-lactamase was $16 \mu \mathrm{g} / \mathrm{ml}$, identical with those of the carbenicillinresistant strains. The rates of hydrolysis of pencillins by this transcipient were four times that of the donor strain 1822 and similar to that of donor strain 3425 . This suggests that the amount of $\beta$-lactamase produced is determined by the recipient cell protein synthesizing system and not by the $R$-factor.

Inhibition profile data (Fig. 2) for this transcipient showed that the profile was similar to those of the carbenicillin-resistant strains and dissimilar from the recipient strain $E$. coli K12. To confirm the validity of this method of characterizing $R$-factor mediated $\beta$-lactamase, a further enzyme obtained from a second transcipient, $E$. coli $\mathrm{K} 12-\mathrm{B} 11_{R}$, was tested, and showed an inhibition profile similar to that of the donor $E$. coli B11 $\beta$-lactamase.

These findings emphasize that $\beta$-lactamases mediated by transmissible $R$-factors may no longer be regarded as being typical of any one species or genus, but could be expected to manifest themsolves in many species of unlike genera.

We thank Dr E. Lowbury for providing the strains of Pseudomonas; Dr G. N. Rolinson and Mr R. Sutherland for helpful discussions; Professor M. Richmond for making his manuscript available while we were preparing this communication; and our colleagues at Beecham Research Laboratories for their assistance.

P. D. F VLLBROOK

S. W. ELSON

B. SLOCOMBE

Beecham Research Laboratories,

Brockham Park,

Betchworth,

Surrey.

Received December 29, 1969; revised February 18, 1970.

1 Lowbury, E. J. K., Kidson, A., Lilly, H. A., Ayliffe, G. A. J., and Jones, R. J., Lancet, ii, 448 (1969).

${ }^{2}$ Sykes, R. B., and Richmond, M, H., Nature (in the press).

${ }^{3}$ Novick, R. P., Biochem. J., 83, 238 (1962),

\section{C-terminal Amino-acid Sequence of Bovine Immunoglobulin Light Chain}

THE C-terminal amino-acid sequences of immunoglobulin light chains of several animal species have been reported ${ }^{1-3}$, and we now wish to document our findings on the bovine light chain $\mathrm{C}$-terminal sequence.

Bovine immunoglobulins $\mathrm{Gl}$ and $\mathrm{G} 2$ were prepared from normal serum by DEAE-cellulose chromatography using gradient elution ${ }^{4}$. A sample of each immunoglobulin was reduced with $5 \mathrm{mM}$ dithiothreitol in aqueous solution and alkylated with iodo[2-14 $\mathrm{C}]$ acetic acid ${ }^{5}$. Light and heavy polypeptide chains were separated by gel filtration on 'Sephadex $G-75$ ' in $1 \mathrm{M}$ propionic acid'. Labelled light chains are then completely reduced in $6 \mathrm{M}$ guanidine- $\mathrm{HCl}$ and alkylated with unlabelled iodoacetic $\operatorname{acid}^{5}$. Completely reduced chains were digested with trypsin and the resulting peptides separated by high voltage paper electrophoresis and by chromatography?

Light chains from both immunoglobulins $G$ gave identical peptide maps having one strongly labelled peptide. Amino-acid analysis ${ }^{7}$ of this peptide indicated the eomposition CM-Cys ${ }_{1}, \mathrm{Thr}_{1}, \mathrm{Ser}_{2}, \mathrm{Glu}_{1}, \mathrm{Pro}_{1}, \mathrm{Val}_{1}, \mathrm{Lys}_{1}$. Treatment of the peptide with carboxypeptidase A (ref. 8) released an appreciable amount of serine together with a small amount of CM-cysteine. N-terminal analysis by the dansyl method ${ }^{\ominus}$ indicated threonine. Sequence analysis by the dansyl-Edman method ${ }^{10}$ showed that valine, lysine, proline and serine occupied positions $2-5$ respectively. Treatment of completely reduced light chain with carboxypeptidase A released serine followed by CMcysteine and glutamic acid.

The C-terminal amino-acid sequence of bovine immunoglobulin light chain is therefore

$$
\underset{T h r}{\rightarrow} \longrightarrow \longrightarrow
$$

which is elearly analogous to the C-terminal sequence of human $\lambda$-type light chain ${ }^{1}$ : Thr-Val-Ala-Pro-Thr-GluCys-Ser, and similar to that of one of the types of pig light chain ${ }^{3}$ : Thr-Val-Thr-Pro-Ser-Glu-Cys-Ala.

D. BEALE

Agricultural Research Couneil,

M. Squires

Institute of Animal Physiology,

Babraham, Cambridge.

Received February 23, 1970.

${ }^{1}$ Milstein, C., Proc. Roy. Soc., B, 168, 138 (1966).

${ }^{2}$ Hood, L., Gray, W. R., Sanders, B. G., and Dreyer, W. J., Cold Spring Harbor Symp. Quant. Biol., 32, 133 (1967).

s Novotny, J., and Franek, F., FEBS Letters, 2, 93 (1968).

${ }^{4}$ Milstein, C. P., and Feinstein, A., Biochem. J., 107, 559 (1968).

"Beale, D., and Feinstein, A., Biochem. J., 112, 187 (1969).

${ }^{6}$ Fleischman, J. B., Pain, R. H., and Porter, R. R., Arch. Biochem. Biophys., Suppl. 1, 174 (1962).

'Beale, D., and Buttress, N., Biochim. Biophys. Acta, 181, 250 (1969).

${ }^{8}$ Ambler, R. P., Biochem. J., 89, 349 (1963).

"Gray, W. R., Methods in Enzymology, 7, II.1.b (1967).

10 Gray, W. R., Methods in Enzymology, 7, VII.c.3 (1967).

\section{Amino-acid Sequence of Slightly Lysine-rich Histone}

KNowledGe of the amino-acid sequence of histones is required to understand the molecular mechanisms of their function in the cell nucleus. Only recently, however, has it become possible to separate quantitatively the individual histones and to characterize the homogeneous components ${ }^{1-12}$. We have developed a new chromato. graphic method using carboxymethyl-cellulose (CMC) with a linearly decreasing concentration of ethanol in $2 \cdot 6 \mathrm{M}$ formic acid containing $0.1 \mathrm{M}$ sodium formate as an eluting agent for fractionation and a new polyacrylamide gel electrophoretic system for the characterization of the histone fractions ${ }^{5}$. We have found that calf-thymus histones comprise five main types which differ in amino acid composition and in electrophoretic mobility: a glycine-rich, arginine-rich histone (also known as f2al or IV); a glutamic-acid-rich, arginine-rich histone (fe or III); a loucine-rich, intermediate type histone (f2a 2 or IIbl); a serine-rich, slightly lysine-rich histone (f2b or IIb2); and an alanine-rich, very lysine-rich histone (fl or I).

We report here the complete amino-acid sequence of the slightly lysine-rich histone, one of the threo types obtained in homogeneous form. The complete sequenco of the glycine and arginine-rich histone from calf thymus has been determined by DeLange et al. ${ }^{13}$ and by Ogawa 